\title{
The effectiveness of secondary education affirmation program (ADEM) for repatriated students in Indonesia: A case study in Lampung province on Sumatra island
}

\author{
I Komang Winatha ${ }^{* *}$ \\ Albet Maydiantoro ${ }^{2}$ \\ Suroto ${ }^{3}$ \\ Fanni Rahmawati ${ }^{4}$ (i) \\ Yon Rizal ${ }^{5}$ (D) \\ ${ }^{1-5}$ Economic Education, Universitas Lampung, Bandar Lampung, Indonesia
}

\begin{abstract}
The Secondary Education Affirmation Program (ADEM) for repatriated students is an effort made by the Indonesian government to provide educational services for students who have difficulties accessing education abroad. The aim of this study was to investigate the effectiveness of the government program implementation in Lampung province on Sumatera island, Indonesia. This study adopted a qualitative approach using interviews for data collection. The collected data were then descriptively analyzed. The result indicates that ADEM program is an effective way for providing access to proper education for repatriated students. However, several learning difficulties during the program implementation, such as differences in language, culture, food, and facilities, need to be taken into account. The study's limitations with several suggestions for future research are also discussed.
\end{abstract}

\section{KEYWORDS}

ADEM; education; government; Indonesia; repatriated students

Received: 29 January 2021 Accepted: 2 February 2021 Published: 3 February 2021

\section{Introduction}

Education is one of the basic rights and needs that should be obtained by all Indonesian citizens. The national education system must be able to ensure equitable distribution of educational opportunities and increase the quality and relevance of education to face the challenges of local, national and global changes (Law Number 20 of 2003). This is an effort to improve the quality of Indonesian human resources in order for them to be able to compete in today's era of globalization. The existences of instructions for the implementations of Law Number 20 of 2003 concerning National Education System, Government Regulation of the Republic of Indonesia Number 47 of 2008 concerning Compulsory Education, and Presidential Instruction Number 5 of 2006 concerning National Movement for the Acceleration of Completion of Nine-Year Compulsory Education and the

\footnotetext{
CONTACT I Komang Winatha @ikomang.winatha@fkip.unila.ac.id
} 
Eradication of Illiteracy are evidence that the Indonesian government has made the effort to improve the quality of human resources to be more competitive.

In Law Number 20 of 2003, Article 5, Paragraph 1, it is clearly stated that every citizen has the same right to obtain quality education. This provision is a formal juridical basis as a legal umbrella as well as a mandate for the government to provide services to children who need special service education in obtaining their educational rights. One of the efforts made by the government to fulfill the mandate is through the implementation of the Secondary Education Affirmation Program (ADEM) for repatriated students, which is under the Directorate of Special Education Development of the Ministry of Education. One of the program's goals was providing access to secondary education for students who have graduated from Kota Kinabalu School of Indonesia (SIKK) and the Sabah-Malaysia Community Learning Center (CLC).

The issue of migrant workers is very strategic. Apart from being related to the large number of workers, problems of great complexity among the workers are also in existence. One of them is the problem of access to education for children of migrant workers abroad, especially those in Malaysia (Wuryandari, 2016). Although there are private schools that can accept them in Malaysia, however, the tuition fees are relatively expensive. Thus, the Indonesian government must continue to strive to provide access to education and ensure the effectiveness of its learning. Looking at this situation, therefore, the aim of the present paper is to investigate the government program implementation in Lampung province on Sumatra island, in particular, to offer additional insight into the effectiveness of the program.

\section{Literature review}

Education is a basic need of every human being to ensure his survival to be more dignified since it can make someone more likely to succeed (Bangun, 2016). Given the difficulty of obtaining education for Indonesian Migrant Workers (TKI) residing in Malaysia which is exacerbated by the alienation status of their children, the absence of permit management regulations, which results in the absence of passports and birth certificates, can make migrant workers vulnerable to arrest during raids (Sulastri, 2017). The Royal Malaysian Government's policy does not recognize the existence of the Indonesian migrant workers' children. Even though they hold passports, not to mention the ones who do not, they are not allowed to attend public schools. The Malaysian government prohibits them from attending public schools because these schools are subsidized by the government for their citizens.

Although there are private schools that can accept Indonesian citizens, the cost of education is relatively expensive (Wintara, 2017; Windary, 2013). Therefore, the Indonesian government must continue to strive to fix these problems in the education sector by creating quality formal schools, especially for Indonesian citizens who are presentative for the equality of Indonesian citizens abroad, especially Malaysia.

Seeing the problems mentioned above, it should be noted that there are rights and obligations, either as human beings or Indonesian citizens, that must be fulfilled. One of the real rights of each individual is the right to access education (Haling et al., 2018), at least at the basic level as stated in the Universal Declaration of Human Rights in Article 26 Paragraph 1. In addition, the right to education is also a basic right inherent in Indonesian citizens that has been confirmed by Law Number 39 of 1999, Article 60 concerning Human Rights, in which the child's right to get education has been clearly confirmed.

\section{Methods}

The study adopted a qualitative approach with a descriptive method. Observation and interview techniques were used to obtain data related to student difficulties, government policies and access obtained by the repatriated students during their participation in ADEM program. This research was conducted among repatriated students, teachers and peers in Lampung province. The 
collected data were analyzed in the forms of data reduction, data presentation, and conclusion drawing, as well as data validity checking by using observation and triangulation.

\section{Results and discussion}

\section{Characteristics of repatriated students}

The environment greatly affects the character development of students (Nurdin, 2020). character is needed by someone in living life (Allan, 2015). Lately, we often encounter news about the quality of adolescent characters. Difficulty in gaining access to education can hamper students' efforts to form good character (Darmayanti \& Wibowo, 2014). Repatriation students residing in Lampung province who are children of Indonesian Migrant Workers (TKI) residing in Sabah, Malaysia.

The fulfillment of education for Indonesian children in the Sabah region, Malaysia is currently still experiencing a number of obstacles. At the policy level, "... there is a prohibition for the children of foreign workers to take part in learning activities at the Malaysian National School" (Kemdikbud, 2019). This situation ultimately affects the student's condition. Complaints such as the difficulty of getting proper education and adequate facilities are often problems that are often faced. Other than that Kemdikbud (2019) revealed "... the fulfillment of education through the Community Learning Center (CLC) which the Indonesian government strives for only providing up to Junior High School (SMP) level, so to continue to the next level, students at CLC must study in Indonesia".

Lack of motivation to continue school, realizing goals, and lack of competence in the use of technology as well as hopelessness often faced by students. Students must be introduced from the beginning about character education to shape their character (Septiadi, et.al., 2019). Education for character building basically includes "... the development of substances, processes and an atmosphere or environment that inspires, encourages, and makes it easier for someone to develop good habits in everyday life" (Gaol \& Sitepu, 2020).

\section{Constraints faced during learning}

Lack of access to existing education can cause learning difficulties. Sriyanti (2013) states "Learning difficulties can be interpreted as problems that can hinder efforts to achieve learning goals". In general, students have not been able to overcome their own learning difficulties. The assistance of teachers, parents and other people around them is needed to overcome them. (Bartram, 2007).

Based on the interviews conducted, some of the obstacles faced by repatriated students in Lampung Province can be seen in Figure 1 below.

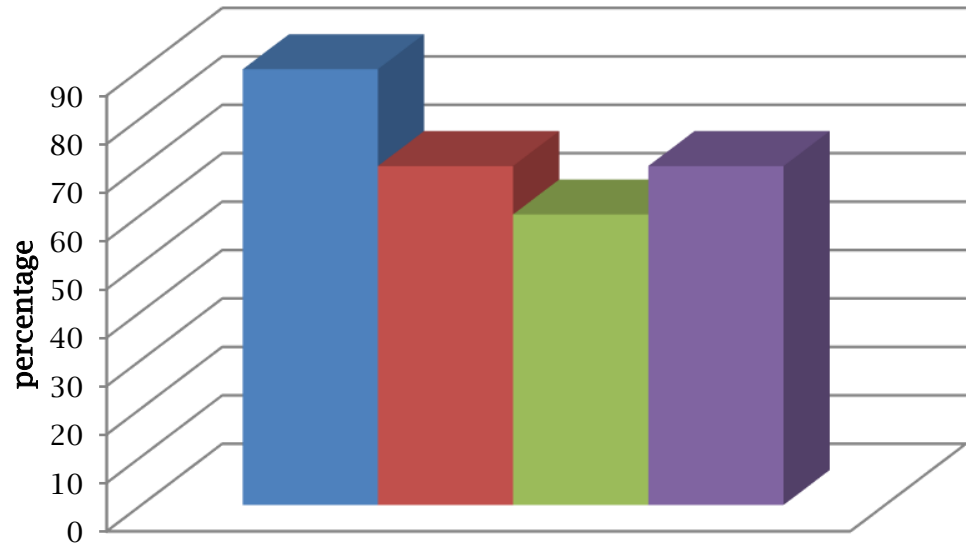

- Languange

- Culture

- Food

- facilities 
Language differences are one of the causes of learning difficulties (Furnham, 2004). The use of different languages can shock students (Zhou et al., 2008). For repatriated students who were born and raised in Sabah, Malaysia, the difference in the language used was a particular difficulty faced. Moreover, there are still teachers and peers who still use local languages in the learning process.

Cultural differences in students in a new environment can also cause learning difficulties for students. Even, Martono et al. (2020) states that “... very different cultures are a major problem that can create learning problems. Enakshi \& Vijay (2020) also states "Ethics in socializing, discipline, and various kinds of old habits make students difficult to adapt to culture in a new environment". Although they are Indonesian citizens, previous repatriated students have never been to Indonesia directly. Because on average, repatriated students studying in Lampung province are children of Indonesian citizens who are classified as underprivileged.

The difference in taste of food can also be an obstacle for repatriation students. Someone who is in a new place often feels unsuitable and easily bored with the taste of cooking in a new environment. However, the food factor is not a problem for some students. In addition, this factor usually resolves over time.

Previous school facilities and infrastructure, namely the inadequate CLCs, became a problem for many students (Lisdiany, 2017), this problem is particularly related to the use of technology in his new school. One of the most common difficulties experienced by students is when using a computer device.

\section{Policy and Access}

As previously discussed, Repatriated students face many obstacles in learning. In order to assist students in facing learning constraints, special attention is needed such as teachers, staff and peers (Bartram, 2007). Provision of more than regular students is deemed necessary to help Repatriated students (Martono et al., 2020). Scholarships, mentoring, matriculation, housing, and good facilities have been awarded to repatriated students. The perceptions of repatriated students towards the program can be seen in Figure 2 below.

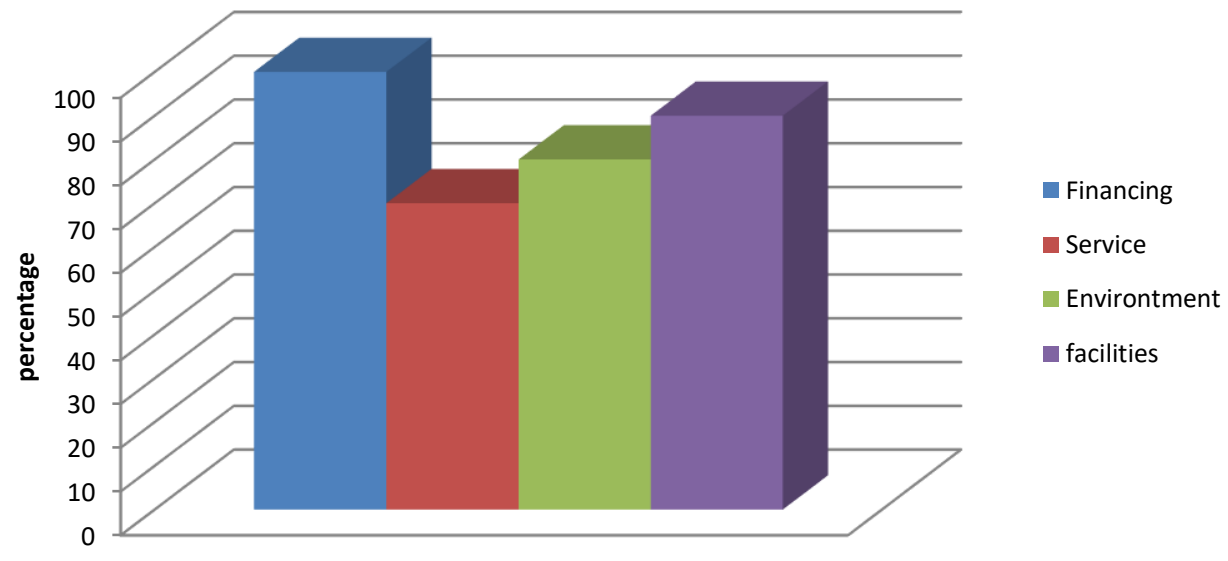

Figure 2. Perceptions of repatriated students towards ADEM program

Based on Figure 2 above, it can be seen that on average, repatriated students feel greatly helped by the implementation of the repatriation ADEM program. Providing scholarships, friends and accompanying teachers, housing, and school facilities that have been provided are felt to be very helpful for repatriated students to be able to realize the success of learning. Scholarships are very helpful for students because the average student's parents come from underprivileged 
families. On average, parents only work as laborers in oil palm plantations. In addition, it is known that scholarships can encourage student motivation to learn (Septianti, 2017).

Peers and co-teachers often accompany and assist repatriated students to understand lessons carefully. Assistance is carried out with matriculation and other activities both at school and outside of school so that repatriated students can adjust to their peers. Peer assistance can also affect student learning outcomes (Izzati, 2015).

The existence of a monitoring and evaluation program on student development also greatly influences and strengthens. Monitoring and evaluation is part of the management function which has a very big role in the quality control system (Martono et al., 2020). During the ADEM program, repatriated students are not only provided with facilities such as other students, they are also given proper housing. The existence of a shared study room and internet access are considered very helpful for students in their daily learning process.

Thus, students and teachers assess that the repatriation ADEM program is effective. Although sometimes there are obstacles to adjustment, teachers and school principals consider that with some more treatment all repatriated students can adjust and be able to achieve good learning outcomes. In the end, Repatriated students who are also an input component in the education system, which are then processed in the education process, are expected to be able to develop into qualified human beings in accordance with the goals of national education. With the ADEM program, Repatriated students are expected to become an example for all parties in order to help all Indonesian people realize their hopes and dreams.

\section{Conclusion}

The implementation of the ADEM Student Repatriation Program is an effort by the Government of Indonesia to provide educational services for students who have difficulty accessing education abroad. The program provided by the Ministry of Education is known to be effective in providing services and access to education for repatriated students. This success is indirectly influenced by the assistance program and is followed by monitoring and evaluation. However, there are several things that often become obstacles to student learning so that it needs to be considered such as differences in language, culture, food and facilities.

\section{Acknowledgements}

We would like to express our gratitude to all parties taking part in this study. Our gratitude also goes to the anonymous reviewers for providing us with constructive comments on the earlier version of this paper.

\section{Funding}

This study was financially supported by Universitas Lampung in 2020.

\section{References}

Allan, B. A. (2015). Balance among character strengths and meaning in life. Journal of Happiness Studies, 16(5), 1247-1261. https://doi.org/10.1007/s10902-014-9557-9

Bangun, S. Y. (2016). Pengembangan pengetahuan anak difabel melalui pendidikan jasmani olahraga dan outbound. Journal Physical Education, Health and Recreation, 1(1), 70. https://doi.org/10.24114/pjkr.v1il.4777

Bartram, B. (2007). The sociocultural needs of international students in higher education: A comparison of staff and student views. Journal of Studies in International Education, 11(2), 205-214. https://doi.org/10.1177/1028315306297731

Darmayanti, S. E., \& Wibowo, U. B. (2014). Evaluasi program pendidikan karakter di sekolah dasar kabupaten Kulon Progo. Jurnal Prima Edukasia, 2(2), 223. https://doi.org/10.21831/jpe.v2i2.2721

Enakshi, S., \& Vijay, K. (2020). Repatriation of Kurdish students and adjustment issues. In Rethinking Education Across Borders: Emerging Issues and Critical Insights on Globally Mobile Students (pp. 211224). Springer Nature Singapore Pte Ltd.

Furnham, A. (2004). Foreign students: Education and culture shock. Psychologist, 171), 16-19. 
Gaol, R. L., \& Sitepu, A. (2020). The Influence of used good-based learning media on the value of chracter education and student's motivation to study. Budapest International Research and Critics in Linguistics and Education (BirLE) Journal, 3(4), 1696-1703. https://doi.org/10.33258/birle.v3i4.1299

Haling, S., Halim, P., Badruddun, S., \& Djanggih, H. (2018). Perlindungan hak asasi anak jalanan dalam bidang pendidikan menurut hukum nasional dan konvensi internasional. Jurnal Hukum \& Pembangunan, 48(2), $361-378$.

Izzati, N. (2015). Pengaruh penerapan program remedial dan pengayaan melalui pembelajaran tutor sebaya terhadap hasil belajar matematika siswa. Eduma: Mathematics Education Learning and Teaching, 4(1). https://doi.org/10.24235/eduma.v4i1.20

Kemdikbud, B. K. dan L. M. (2019). Mendikbud pastikan semua anak wni mendapatkan hak pendidikan. https://www.kemdikbud.go.id/main/blog/2019/02/mendikbud-pastikan-semua-anak-wni-mendapatkanhak-pendidikan

Lisdiany, S. S. (2017). Upaya Indonesia memenuhi hak pendidikan bagi anak TKI dan Pati di Johor Bahru (20142017). In Repository.Uinjkt.Ac.Id. http://repository.uinjkt.ac.id/dspace/handle/123456789/43594

Lumpur, A. K. (2019). Program repatriasi siswa CLC di Malaysia. Atdikbud Kuala Lumpur. https://atdikbudkl.org/2019/06/24/program-repatriasi-siswa-clc-di-malaysia/

Martono, T., Baedhowi, B., Sawiji, H., Totalia, S. A., Wahyono, B., \& Octoria, D. (2020). The effectiveness of high school affirmations (adem) repatriation: Empirical evidence from Central Java and Special Region of Yogyakarta, Indonesia. Budapest International Research and Critics in Linguistics and Education (BirLE) Journal, 3(4), 1841-1847. https://doi.org/10.33258/birle.v3i4.1380

Nurdin, A. (2020). The influence of the learning environment in student character building. Tarbawi: Jurnal Keilmuan Manajemen Pendidikan, 6(02), 175. https://doi.org/10.32678/tarbawi.v6i02.3042

Republik Indonesia. (1999). Undang-Undang No. 39 Tahun 1999 Tentang Hak Asasi Manusia. Lembaran Negara RI tanggal 23 September 1999. Jakarta: Menteri Negara Sekretaris Negara Republik Indonesia

Republik Indonesia. (2006). Instruksi Presiden Republik Indonesia Nomor 5 Tahun 2006 Tentang Gerakan Nasional Percepatan Penuntasan Wajib Belajar Pendidikan Dasar Sembilan Tahun Dan Pemberantasan Buta Aksara. Jakarta: Deputi Sekretaris Kabinet Bidang Hukum

Republik Indonesia. (2008). Peraturan Pemerintah Republik Indonesia Nomor 47 tahun 2008 tentang Wajib Belajar. Jakarta: Menteri Hukum Dan Hak Asasi Manusia Republik Indonesia

Septiadi, H. N., Andayani, A., \& Wardani, N. E. (2019). Planting base value of hardworking character education through ulid novel. Budapest International Research and Critics in Linguistics and Education (BirLE) Journal, 2(3), 28-36. https://doi.org/10.33258/birle.v2i3.350

Septianti, D. (2017). Pengaruh pemberian beasiswa bidik misi terhadap motivasi berprestasi dan disiplin mahasiswa penerima beasiswa bidik misi di Palembang. Jurnal Ilmiah Ekonomi Global Masa Kini, 8(2), 611.

Soba, H. (2021). 152 Anak pekerja migran lanjutkan pendidikan di tanah air. https://www.beritasatu.com/nasional/715403/152-anak-pekerja-migran-lanjutkan-pendidikan-di-tanahair

Sriyanti, L. (2013). Psikologi belajar. Yogyakarta: Ombak.

Undang-undang Republik Indonesia Nomor 20 Tahun 2003 Tentang Sistem Pendidikan Nasional. (2003). Jakarta: Sekretaris Negara Republik Indonesia

Wuryandari, G. (2016). Diplomasi bilateral Indonesia dalam isu pekerja migran. In N. Sriyanto, R. E. Yustiningrum, G. Wuryandari, \& A. N. Alami, Politik Luar Negeri Indonesia dan Isu Migrasi Internasional. Graha Ilmu.

Zhou, Y., Jindal-Snape, D., Topping, K., \& Todman, J. (2008). Theoretical models of culture shock and adaptation in international students in higher education. Studies in Higher Education, 33(1), 63-75. https://doi.org/10.1080/03075070701794833 